\title{
EFFECT OF TREATMENT WITH NANO-Se AND VITAMIN E ON SEMEN QUALITY AND SOME BLOOD PARAMETERS OF BUCK RABBITS
}

\author{
Noura H. Gouda; H. M. El-Kelawy; M. Abd-El-Rahim; M.N. El-Gaafary \\ and H. Ibrahim \\ Department of Animal and Poultry Production, Faculty of Technology \& \\ Development, Zagazig University, Zagazig, Egypt. \\ e.mail:drhassan_2105@yahoo.com,mostafarahim@ymail.com
}

\section{ABSTRACT}

This study aimed to investigate the effects of Nano-selenium (Nano-Se), organic selenium $(\mathrm{Org}-\mathrm{Se})$, vitamin $\mathrm{E}$ and their combination on semen quality and some blood parameters of New Zealand White bucks rabbits (NZW). A total number of 24 NZW with $2671 \pm 185$ initial body weight and 24 weeks of age were used in the study. The bucks were randomly allotted to three experimental main groups. The $1^{\text {st }}$ group fed basal diet and served as a control. The $2^{\text {nd }}$ group fed basal diet and orally treated with $0.5 \mathrm{mg}$ Org- Se / $\mathrm{kg}$ body weight $(\mathrm{BW})$. The $3^{\text {rd }}$ group fed basal diet and orally treated with $0.5 \mathrm{mg} \mathrm{Nano-Se} / \mathrm{kg} \mathrm{BW}$. The experimental groups were divided according to Vitamin $E$ administration into two sub groups. The $1^{\text {st }}$ sub group was left as a control (without vitamin E administration) and the $2^{\text {nd }}$ sub group orally treated with $250 \mathrm{mg}$ Vit. E/ $\mathrm{kg} \mathrm{Bw}$. Physical semen characteristics and hematological and biochemical blood parameters were studied.

Mean values of physical semen characteristics were significantly higher $(P<0.01)$ for buck rabbits fed diets with selenium sources and vitamin $E$ as compared with those fed on basal diet (control). RBCs, $W B C s$, blood platelets, hematocrit, $M C V$ and MCHC, were within the normal physiological range and the differences were not significantly affected by treatment with selenium sources. However, $\mathrm{Hb}, \mathrm{MCH}$ and lymphocytes percentages were significantly increased $(P<0.05$ and $P$ $<0.01)$ for buck rabbit's fed basal diet with Nano selenium. The mean values of RBCs, Hb, hematocrit, MCHC and lymphocytes percentages were significantly higher $(P<0.05$ and $<P$ 0.01) in buck rabbits fed basal diet with vitamin $E$ than un-treated rabbits. However, the mean values of blood platelets and neutrophils percentages were significantly higher $(P<0.05$ or $P<0.01)$ in buck rabbits fed basal diet without vitamin $E$ than those fed diet with vitamin $E$. Total protein and globulin were significantly increased $(P<0.05$ and $P<0.01)$ while, albumin and 
AL/GL ratio, were not significantly affected by selenium sources. Total protein was significantly improved $(P<0.01)$ in buck rabbits fed basal diet with vitamin $E$ when compared with un-treated with vitamin $E$. Total cholesterol concentrations and triglycerides were significantly lower $(P<0.05$ or $P<0.01)$ for rabbits fed basal diet with selenium sources or vitamin $E$ than control group. ALT was increased $(P<0.01)$ in rabbits fed basal diet with Nano selenium when compared with the other groups. The mean values of creatinine and blood urea- $N$ were not significantly affected by selenium sources and Vit. $E$ treatment. Testosterone concentrations in seminal plasma and blood serum were significantly increased $(P<0.05$ and $P<0.01)$ in buck rabbits fed basal diet and treated with Nano selenium group compared with the other groups. The mean values of testosterone concentration in seminal plasma and blood serum were insignificantly affected by treatment with Vit E. The highest values of testosterone concentration in seminal plasma and blood serum were recorded with buck rabbits fed basal diet and treated with Nano-Se plus Vit E groups.

In conclusion, orally treatment of buck rabbits with selenium sources (Nano-Se or Org-Se) without or with vitamin E had improved semen quality and hematological and biochemical blood parameters. From the results of present experiment, it is recommended to support the commercial basal diet of buck NZW rabbits by orally treatment of rabbits with $0.5 \mathrm{mg}$ Organic- Se / $\mathrm{kg} \mathrm{Bw}$ to maintain their health status, protect them from heat stress and improve their semen quality in hot climate of Egypt in summer season.

Key word: Nano-selenium, Vit. E, semen quality, blood parameters, bucks rabbits.

\section{INTRODUCTION}

Heat stress is the most obvious limitation to rabbit production in hot climate area. Heat stress evokes a series of drastic changes in their biological functions that lead to impairment of production and reproduction (Marai et al., 1991; Fernandez et al., 1994 and Marai and El-Kelawy, 1999). Such detrimental effects are obviously seen during summer, and are reflected in limiting the breeding season of rabbits (Marai et al.1996). In North African countries rabbit industry has developed rapidly, and applied research on vital aspects of rabbit production such as economics, housing, management, nutrition and reproduction are urgently needed to ensure a high success rate of rabbit development, which could have a favorable economic and nutritional impact. Dietary selenium is an essential trace element for normal animal growth, 
fertility, immunity physiology and metabolism as well as external and internal organs (Mohapatra et al., 2014). Selenium improves productive performance and antioxidant status of animals, particularly in hot summer environments (Mahima et al., 2012).

Selenium can be supplemented in the form of organic, inorganic, and nanoparticles; however, nanoparticles of selenium possess comparable efficiency, high bioavailability, high catalytic efficiency, strong adsorbing ability, and low toxicity compared with other selenium sources (Wang et al., 2009).

Vitamin $\mathrm{E}$ is one of the best antioxidants for the removal of oxidative stress in male reproductive system. Its use increases the reproductive functions and efficiency of male reproductive system. The deficiency of this vitamin leads to degeneration of germinal epithelium and Leydig cells in seminiferous tubules (Muhammad Zubair, 2017).

Therefore, the present study was carried out to study the effects of dietary inclusion of Nano-selenium (Nano-Se), organic- Se, with or without vitamin $\mathrm{E}$ on semen quality and health status of New Zealand White (NZW) bucks rabbits, under heat environmental of Egypt in summer.

\section{MATERIALS AND METHODS}

The experimental work of the present study was carried out at Rabbits Research Unit, Department of Animal and Poultry Production, Faculty of Technology and Development, Zagazig University, Zagazig, Egypt. The experimental work was initiated in July 2019 and terminated in, August 2020. The present experiment was conducted at sexual maturity of bucks ( 24 weeks of age). The semen quality and chemical analysis of ingested feed were performed at Central Lab for Soil, Foods and Feedstuffs (International accredited Laboratory, has ISO 17025, since 2012) belongs to Faculty of Technology \& Development, Zagazig University, Zagazig, Egypt. Analysis of blood samples, were conducted in private medical Lab., Zagazig, Egypt.

A total number of 24 NZW bucks rabbits with $(2671 \pm 185 \mathrm{~g})$. initial body weight and 24 weeks of age were used. The bucks were randomly allotted to three experimental main groups. The $1^{\text {st }}$ group fed basal died and served as a Control. The $2^{\text {nd }}$ group fed basal diet and orally treated with 0.5 mg Org- Se / kg body weight (BW). The $3^{\text {rd }}$ group fed basal diet and orally treated with $0.5 \mathrm{mg}$ Nano-Se $/ \mathrm{kg} \mathrm{BW}$. The experimental groups were divided according to Vitamin $\mathrm{E}$ administration into two sub groups. The $1^{\text {st }}$ sub group was left as a control (without vitamin $\mathrm{E}$ administration) and the $2^{\text {nd }}$ sub group orally treated with $250 \mathrm{mg}$ Vit. E/ kg BW. 
Samples from the basal diet were taken for chemical analysis to determine crude protein, crude fiber, ether extract and nitrogen free extract according to the International Standard Methods (ISO). Moisture content was determined according to ISO 6496: 1999, crude ash according to ISO 5984:2002, crude protein according to ISO 5983-1:2002, crude fat according to the method described in Official Journal of the European Union (EN), 2009, L54/ 37, Volume 52, and crude fiber was according to the method described in Official Journal of the European Union (EN), 2009, L54/40, Volume 52. The diets were formulated to meet the nutrient requirements of rabbits for reproduction according to NRC (1977). Ingredients and chemical composition of the basal diet are shown in Table 1.

Semen samples were collected once weekly for eight consecutive weeks using an artificial vagina device as described by Walton (1958). Each ejaculate was taken to measure physical semen characteristics (ejaculate volume, wave motion, progressive liner motility, sperm concentration, live and abnormal spermatozoa and total sperm output) according to El-Gaafary (1987).

In the end of experiment, three rabbits from each group were slaughtered and blood samples $(5 \mathrm{ml} /$ each rabbit) were collected. Each sample was taken into two tubes; the first was heparinized and the second tube was non-heparinized. The heparinized blood samples were used to test the hematological parameters (red blood cells $\left(\mathrm{RBC}_{\mathrm{S}}\right)$, hemoglobin $(\mathrm{Hb})$, haematocrit $(\mathrm{HCT})$, mean cell volum (MCV), mean cell haemoglobin $(\mathrm{MCH})$, mean cell haemoglobin concentration (MCHC), white blood cells (WBCS), neutrophils, lymphocyte and platelets). Non-heparinized blood samples were immediately centrifuged at 3000 r.p.m. for 15 minutes and serum was separated, frozen under $-20^{\circ} \mathrm{C}$, and kept for biochemical analysis (total protein, albumen, globulin, albumen globulin ratio, triglycerides, cholesterol, aspartate amino-transferase (AST), alanine amino-transferase (ALT), Urea-N and creatinine) and testosterone.

\section{Statistical analysis:}

Data of the present study were statistically analyzed using Least Squares Analysis of Variance according to Snedecor and Cochran (1982) using the General Linear Model Program of SPSS (2014) using the following fixed model for bucks:

$$
\mathrm{Yij}=\mu+\mathrm{Si}+\mathrm{V}_{\mathrm{j}}+\mathrm{SV}_{\mathrm{ij}}+\mathrm{eij}
$$

Where, Yij $=$ The observed value of a given dependent variable, $\mu=$ Overall adjusted mean, $\mathrm{Si}=$ Forms of selenium effect $(\mathrm{i}=1,2$ and 3$), \mathrm{V}_{\mathrm{j}}=$ 
Table 1: Ingredients and chemical analysis of the basal diet.

\begin{tabular}{ll}
\hline Ingredient & \% of total diet \\
\hline Yellow corn & 16.00 \\
Barley & 18.00 \\
Wheat bran & 26.00 \\
Soybeans & 19.3 \\
Alfalfa hay & 18.00 \\
Limestone & 2.00 \\
Salt & 0.50 \\
Methionine & 0.10 \\
Anti Mycotoxins & 0.10 \\
\multicolumn{1}{c}{ Total } & $\mathbf{1 0 0}$ \\
\hline Chemical analysis: & \\
Moisture & 10.65 \\
Crude protein & 17.85 \\
Ether extract & 2.30 \\
Crude fiber (cf) & 13.40 \\
Ash & 8.25 \\
Nitrogen free extract (NFE) & 47.55 \\
Lysine* & 0.99 \\
Total Calcium(ca) & 0.88 \\
Total phosphorous (P) & 0.52 \\
Meth+cysteine* & 0.65 \\
\hline
\end{tabular}

* It was calculated according to NRC (1977).

Natural ingredients contain $0.38 \mathrm{mg} \mathrm{Se} / \mathrm{kg}$ feed and $38.4 \mathrm{mg}$ Vit E / $\mathrm{kg}$ feed.

Vit. $\mathrm{E}$ effect $(\mathrm{J}=1$ and 2$), \mathrm{SV}_{\mathrm{ij}}=$ Interaction effect $(\mathrm{ij}=1,2 \ldots$ and 6$)$, eij $=$ Random error.

The differences between LSM (least square means) were analyzed by Duncan's New Multiple Range test (Duncan, 1955).

\section{RESULTS AND DISCUSSION}

\section{Physical semen characteristics of NZW buck rabbit.}

Data in Table 2 shows that semen quality (ejaculate volume, wave motion, progressive linear motility, sperm concentrations, abnormal spermatozoa percentages, live spermatozoa percentages and total sperm 


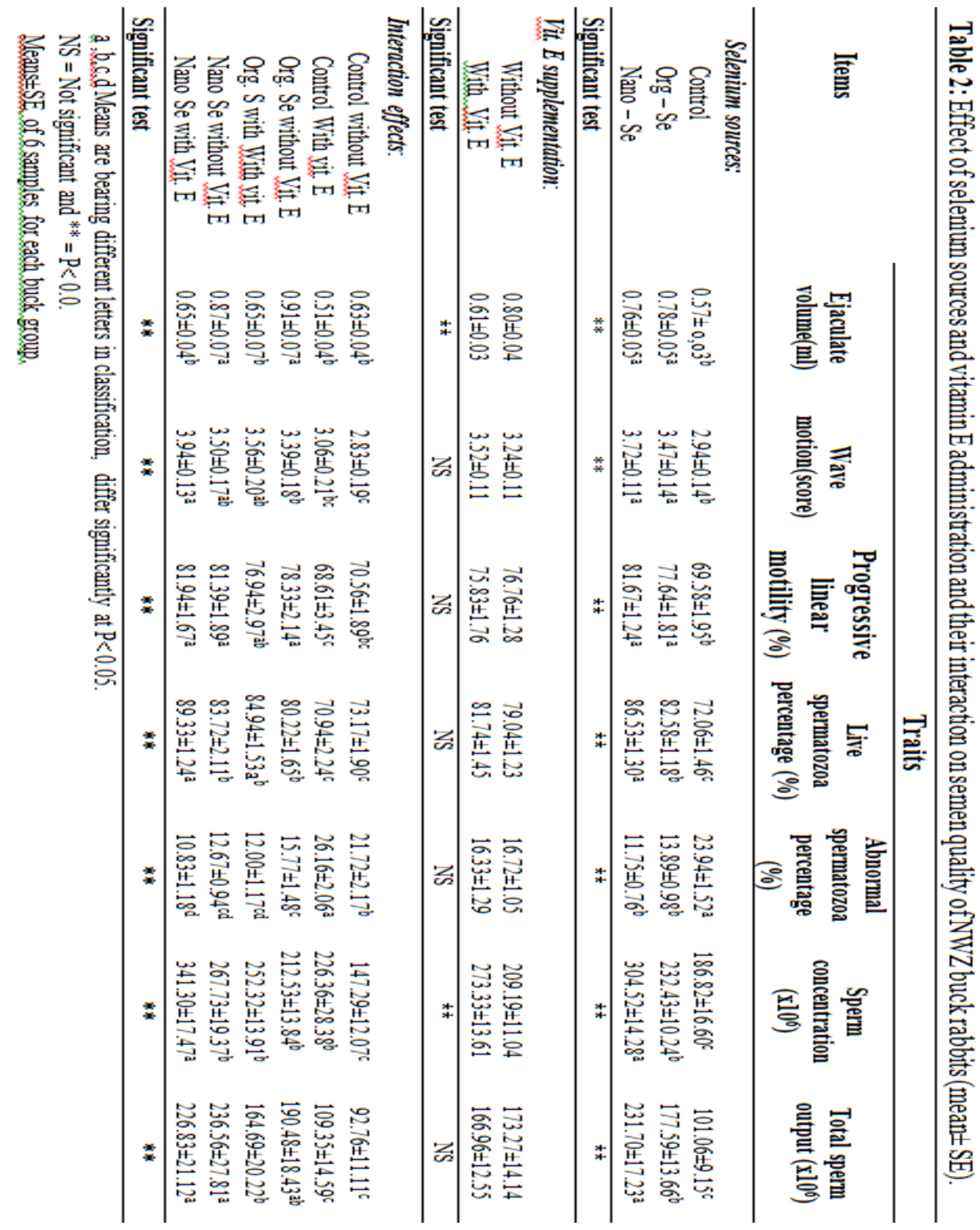


output) were significantly $(\mathrm{P}<0.01)$ improved for bucks rabbits fed basal diet plus org-Se or Nano-Se as compared with control group. These results are in agreement with those obtained by Rezvanfar et al., (2013). Feeding Nano-Se increased ejaculates volume, wave motion and sperm motility in Californian male rabbits. Also, Saber Abd-Allah and Hashem (2015) found that dietary supplementation with Nano-Se increased live sperm, sperm concentrations and total sperm output in rats. The same author added that increased number of sperm in rat's epididymis is due the increase of cell population in the seminiferous tubules and increased sperm vitality and motility after selenium nanoparticles administration.

The mean values of ejaculate volume were significantly increased $(\mathrm{P}<0.01)$ in buck rabbits fed basal diet without vitamin $\mathrm{E}$ than those supplemented with vitamin E. However, the mean values of sperm concentrations were significantly higher $(\mathrm{P}<0.01)$ in buck rabbits fed basal diet and orally treated with vitamin $\mathrm{E}$ when than non-treated rabbits. On the other hand, the mean values of live spermatozoa percentages, wave motion, progressive linear motility, abnormal spermatozoa percentages and total sperm output were not significantly affected by vitamin E treatment (Table 2).

The interaction effects between orally treatment with selenium source and vitamin $\mathrm{E}$ revealed that there were significant differences $(\mathrm{P}<0.01)$ in all semen quality traits studied each of ejaculate volume, wave motion, progressive linear motility, sperm concentrations, abnormal spermatozoa percentages, live spermatozoa percentages and total sperm output. The highest values of wave motion, sperm motility, sperm concentrations and live spermatozoa percentages were obtained with NZW buck rabbits fed basal diet and treated with Nano Se and Vit. E when compared with other treatment groups. Values of abnormal spermatozoa percentages were the highest with NZW buck rabbits fed basal diet with Vit. E when compared with other treatment groups. These results agreed with those reported by Yaseen et al., (2016) who found that semen quality was significantly higher in rabbit bucks received Vit. E and selenium than control rabbit bucks.

\section{Biochemical components of seminal plasma of NZW buck rabbit.}

Table 3 shows that the mean values of total protein and globulin were significantly $(\mathrm{P}<0.05)$ increased in rabbits fed the basal diet and orally treated with organic selenium and Nano selenium than those fed the control diet, but cholesterol and ALT were significantly $(\mathrm{P}<0.01)$ increased in rabbits fed basal diet (control) compared with the other treatment groups. However, albumin and AST levels were not significantly affected by OrgSe or Nano-Se treatment. Ghodaia (2016) reported that seminal plasma 
NOURA GOUDA et al.

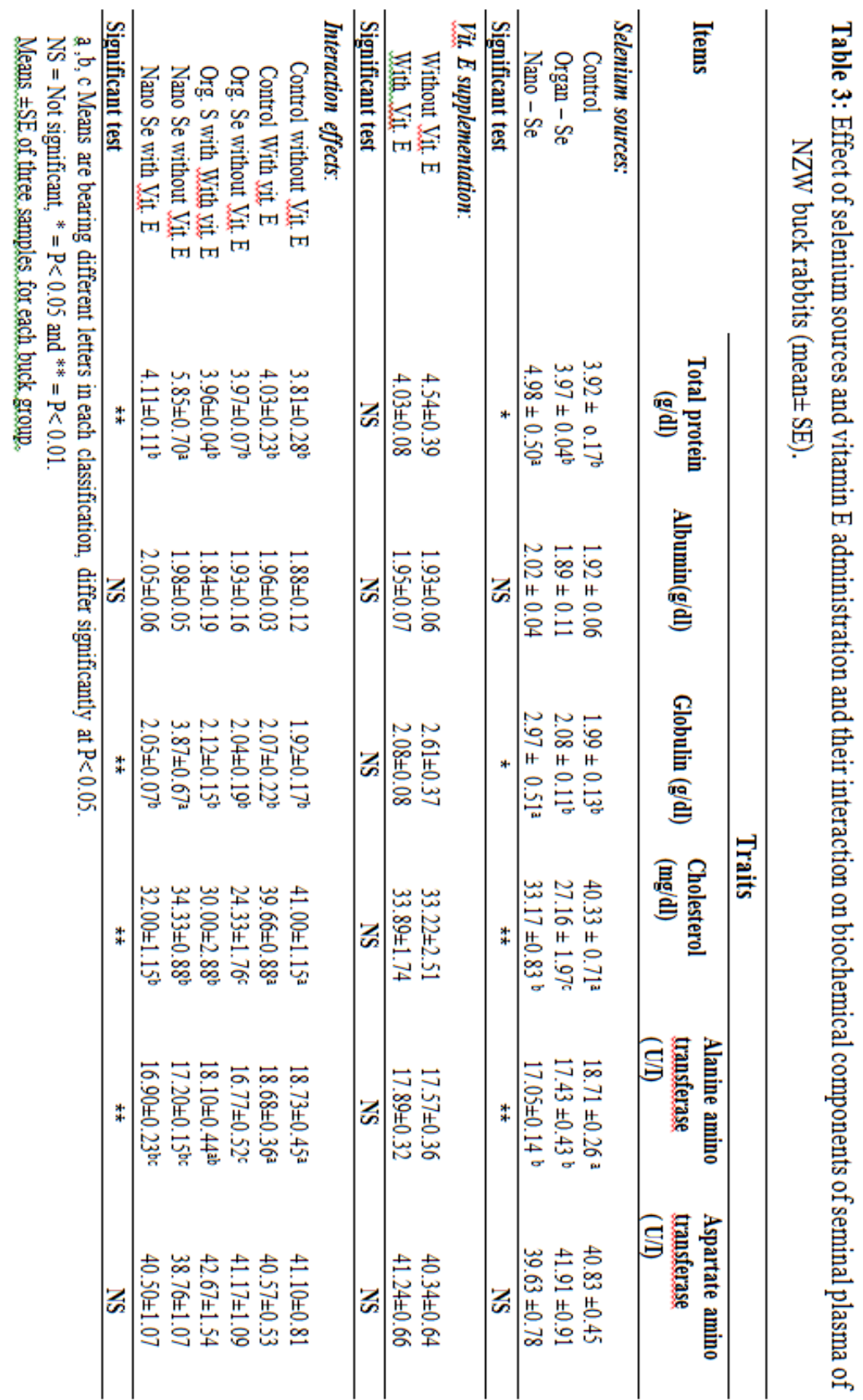


proved to be of great biochemical interest as it contains many organic compounds. These substances produced by various accessory glands in response to testosterone hormone (El-Sherbieny, 2004).The biochemical components in seminal plasma play a biovital role in providing substrate energy forming essential link in the energy generating cycles in sperm metabolism, during the process of fertilization and in the maintenance of constant osmotic pressure during semen preservation (Dhami and Kodagali, 1987). Estimation of these biochemical components in the ejaculated semen or directly in the glands can be used as an index of accessory glands function (White, 1976).

The mean values of total protein, globulin, cholesterol, albumin, ALT and AST were not significantly affected by vitamin E treatment. The interaction effects between selenium source and vitamin $\mathrm{E}$ were significant $(\mathrm{P}<0.05, \mathrm{P}<0.01)$ in total protein, globulin, cholesterol and ALT. However, albumin and AST levels were not significantly affected by selenium source and vitamin E. The highest values of total protein and globulin were obtained with NZW buck rabbits fed basal diet and treated with Nano-Se when compared with other treatment groups. The highest values of cholesterol and ALT were obtained with NZW buck rabbits fed basal diet with Vit E. On the other hand, the lowest values of cholesterol and ALT were recorded with NZW buck rabbits fed basal diet and treated with OrgSe and Vit E when compared with other treatment groups (Tables 3).

Blood parameters of rabbits:

Hematological blood parameters:

The present results in Table 4 show that means of RBCs, WBCs, blood platelets, hematocrit, MCV and MCHC, were within the normal physiological range (Hewitt et al., 1989) and the differences were not significantly affected by selenium sources administration. However, $\mathrm{Hb}$, $\mathrm{MCH}$ and lymphocytes percentage were significantly increased $(\mathrm{P}<0.05$ and $\mathrm{P}<0.01$ ) for buck rabbit's fed basal diet with Nano Se. On the other hand Neutrophils percentage was significantly decreased $(\mathrm{P}<0.01)$ for buck rabbit's fed basal diet with Nano selenium. The mean values of RBCs, $\mathrm{Hb}$, hematocrit, MCHC and lymphocytes percentage were significantly higher $(\mathrm{P}<0.05$ and $<\mathrm{P} 0.01)$ in buck rabbits fed basal diet with vitamin $\mathrm{E}$ administration than un-treated rabbits. However, the mean values of blood platelets and neutrophils percentage were significantly higher $(\mathrm{P}<0.05$ and $\mathrm{P}<0.01)$ in buck rabbits fed basal diet without vitamin $\mathrm{E}$ than those fed basal diet and treated with vitamin $\mathrm{E}$ 


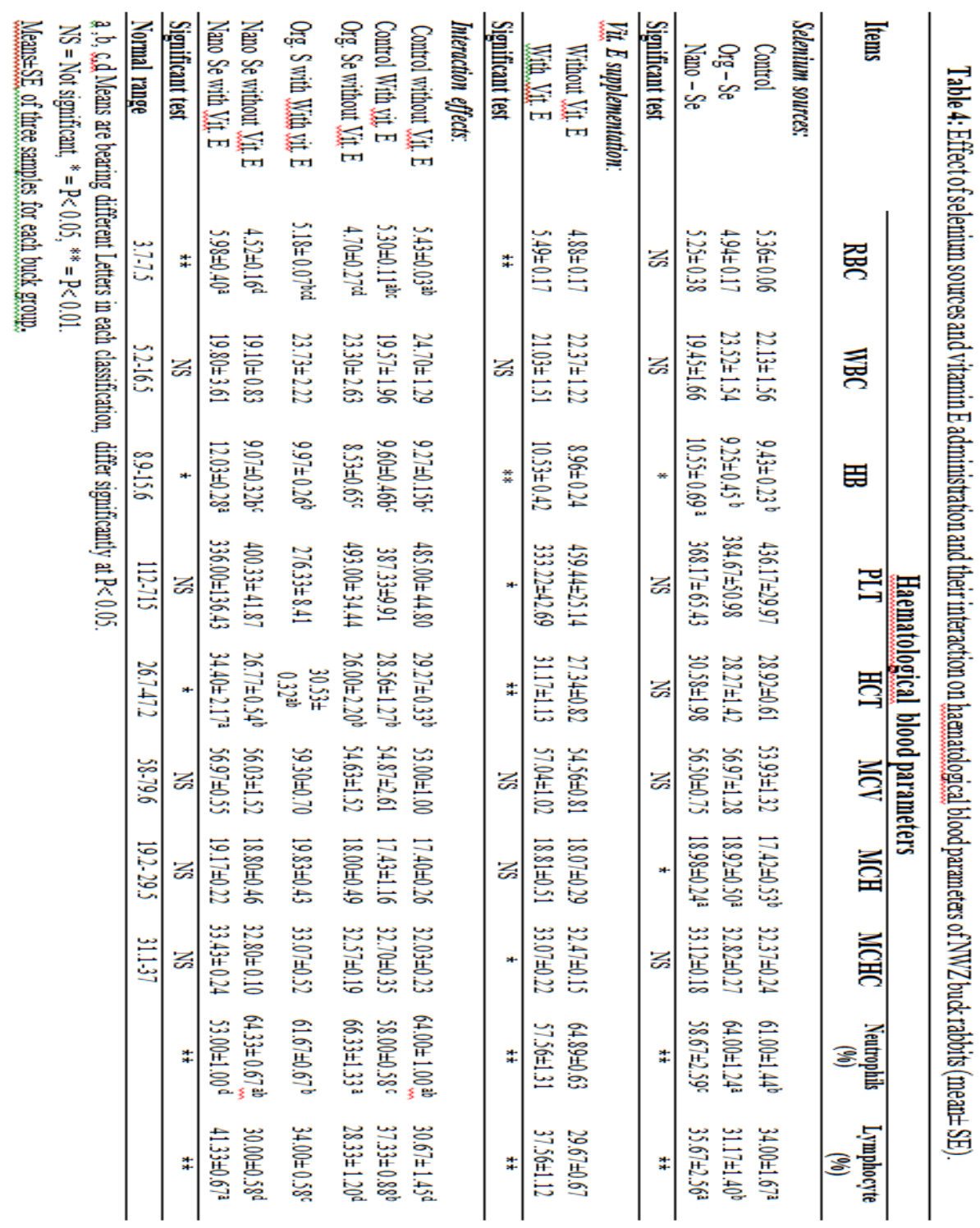


administration. On the other hand, the mean values of WBCs, MCV and $\mathrm{MCH}$ were not significantly affected by vitamin E, as shown in Table 4 .

These results are in agreement with those obtained by Hashem et al. (2013) and Okachi and Ani (2016) who showed that Hb and RBC were significantly $(\mathrm{P}<0.05)$ higher by supplemented diets with Vit. E, while MCV were not significantly $(\mathrm{P}<0.05)$ affected by Vit. E supplementation. Ayyat $e t$ al. (2018) reported that blood HB significantly increased in rabbits fed diet supplemented with $0.3 \mathrm{mg}$ org-Se/ $\mathrm{kg}$ diet.

The interaction effects between administration of selenium source and vitamin $\mathrm{E}$ were significant $(\mathrm{P}<0.05$ and $\mathrm{P}<0.01)$ in $\mathrm{RBCs}, \mathrm{Hb}$, hematocrit, neutrophils and lymphocytes percentage. However, WBCs, MCV, MCH, MCHC and blood platelets levels were not significantly affected by administration of selenium source and vitamin E. Highest values of RBCs, $\mathrm{Hb}$, Hematocrits and lymphocytes percentage were obtained with NZW buck rabbits fed basal diet supplemented diet with Nano Se and Vit E when compared with other treatment groups. However, the highest values of neutrophils were obtained with NZW buck rabbits fed basal diet and treated with organic selenium when compared with other treatment groups, as shown in Table 4. These results are in agreement with those obtained by Hashem et al. (2013) and Okachi and Ani (2016).

\section{Biochemical blood parameters: \\ Protein fractions:}

Total protein and globulin were significantly increased $(\mathrm{P}<0.05$ and 0.01 ), while, albumin and AL/GL ratio, were not significantly affected by selenium administration sources. Total protein was significantly improved $(\mathrm{P}<0.01)$ in buck rabbits fed basal diet and treated with vitamin $\mathrm{E}$ when compared with un-treated with vitamin E (Table 5). These results are in agreement with those obtained by El-Badry et al. (2019) who found that the values of total protein contents in blood was significantly $(\mathrm{P}<0.01)$ increased in rabbits fed Nano-Se followed by those fed the Org-Se as compared with those fed the control diet. Ebeid, (2012) observed no significant effect on albumen level, among rabbits fed diets treated with vitamin $\mathrm{E}$ or selenium diets for 6 weeks.

The interaction effects between selenium sources and vitamin $\mathrm{E}$ were significant $(\mathrm{P}<0.01)$ in total protein and globulin, however, insignificantly differences were observed in albumin and AL/GL ratio. The highest values of globulin were obtained with NZW buck rabbits fed basal diet and treated with Nano Se alone. On the other hand, the lowest values of total protein and globulin were obtained with NZW buck rabbits fed basal diet with Org- 


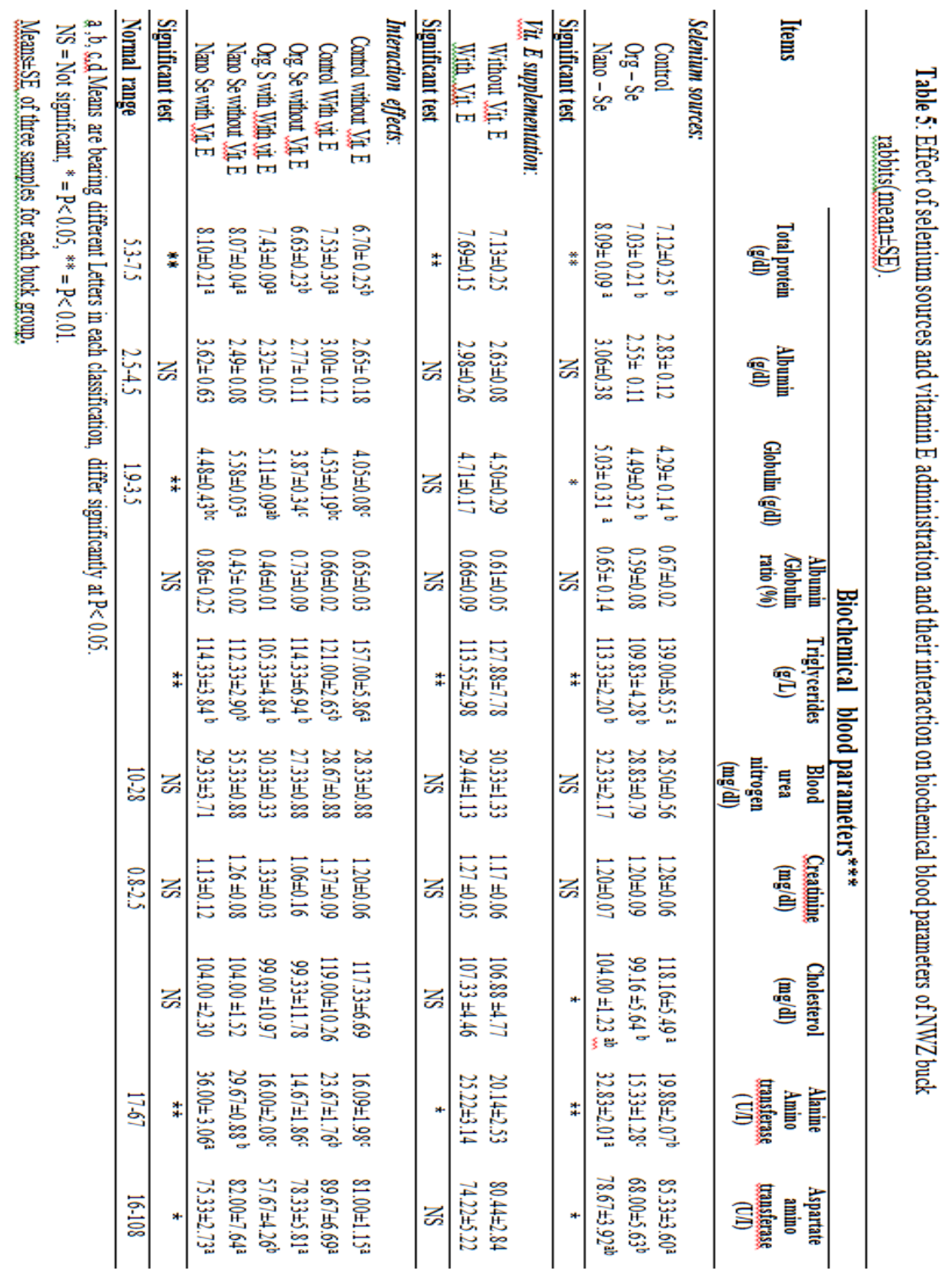


Se plus vitamin E. These results are in agreement with those obtained by El-Kholy et al. (2012) who reported that the improvements of blood components as a result of dietary supplementation with selenium sources was due to the improvement in the immune response. In this concern, Tietz (1986) reported that increase of globulin concentration is important for immunologic responses. Also, Ismail et al. (2003) stated that albumin/globulin ratio is a good indicator for improved immunity. Fortun-Lamothe and DrouetViard, (2002) indicated that treatment with Se sources or Vit E supplementation resulted in increase of the immune system.

\section{Lipid fractions:}

Data in Table 5 show that the total cholesterol concentrations and triglycerides were significantly lower $(\mathrm{P}<0.05$ or $\mathrm{P}<0.01)$ for rabbits fed basal died and orally treated with selenium sources than the control group. The reason of this reduction may be due to the vital role of Se in dominant effects of thyroid $\left(\mathrm{T}_{3}\right)$ hormone on fat metabolism (Masukawa et al., 1983). Hypercholesterolemia has been found to be related with Se, which is related to the improvement in 3- hydroxy-3-methylglutary CoA reductase, which stimulates the microsomes of liver activity (Nassier et al., 1997). Selenium is a component of activity of the glutathione peroxidase (GSH-Px), which plays a vital role as an anti-oxidant enzyme affects on lowering cholesterol syntheses.

The mean values of triglycerides were significantly higher $(\mathrm{P}<0.01)$ in buck rabbits fed basal diet without vitamin $\mathrm{E}$ than diet with vitamin $\mathrm{E}$ administration, However, the mean values of total cholesterol were insignificantly affected by Vit. E treatment (Table 5). Triglycerides for buck rabbits fed basal diets supplemented with selenium source and vitamin E were significantly lower $(\mathrm{P}<0.01)$ than those control group. However, total cholesterol concentrations were not significantly affected by selenium sources and vitamin E treatment (Table 5).

\section{Liver function:}

Alanine amino transferase (ALT) was increased $(\mathrm{P}<0.01)$ in rabbits fed basal diet with Nano selenium when compared with the other groups. However, aspartate amino transferase was increased $(\mathrm{P}<0.05)$ in rabbits fed basal diet (control) as compared with rabbits fed basal diet with selenium sources. These results are in agreement with those obtained by AbdelWareth et al. (2019) who observed that rabbits fed diets with Nano-Se showed lower $(\mathrm{P}<0.01)$ serum levels of aspartate aminotransferase (AST) activities than those fed the un-supplemented diet. El-Deep et al. (2017) reported that 
birds fed either Nano-Se or Se enriched yeast (Sel-Plex) recorded lower values of AST enzyme than control group.

The mean values of ALT were significantly higher $(\mathrm{P}<0.05)$ in buck rabbits fed basal diet and orally treated with vitamin $\mathrm{E}$ than untreated diet, while the mean values of AST were not significantly affected by Vit E treatment (Table 5).

ALT and AST for buck rabbits fed basal diets and orally treated with selenium source and vitamin $\mathrm{E}$ were significant $(\mathrm{P}<0.05$ or $\mathrm{P}<0.01)$. The highest values of ALT and the lowest values of AST were recorded with NZW buck rabbits fed basal diet and treated with Nano selenium plus Vit E.

\section{Kidney function:}

Results in Table 5 show insignificant differences were obtained in blood urea-N and creatinine for buck rabbits fed basal diet and treated with selenium sources as compared with bucks fed basal diet (control) only. AbdelWareth et al. (2019) found that serum urea- nitrogen, and creatinine significantly decreased $(\mathrm{P}<0.05)$ in rabbits fed diet and treated with Nano-Se when compared with those fed un-treatd rabbits.

The mean values of creatinine and blood urea-N were not significantly affected by Vit E administration. Creatinine and blood urea-N concentrations were not significantly affected by the interaction between selenium source and vitamin E (Table 5).

\section{Testosterone concentration:}

Table 6 show that testosterone concentrations in seminal plasma and blood serum were significantly increased $(\mathrm{P}<0.05$ and $\mathrm{P}<0.05$, respectively) in buck rabbits fed basal diet with Nano selenium administration as compared with the other groups. These results are in agreement with those obtained by Rezvanfar et al., (2013) who reported that feeding Nano- selenium increased testosterone concentration in semen.

The mean values of testosterone concentration in seminal plasma and blood serum were insignificantly affected by Vit E treatment. Testosterone concentrations in seminal plasma and blood serum for buck rabbits fed basal diets supplemented with selenium source and vitamin $\mathrm{E}$ were significant $(\mathrm{P}<$ 0.05 or $\mathrm{P}<0.01)$. The highest values of testosterone concentration in seminal plasma and blood serum were recorded with NZW buck rabbits fed basal diet and orally treated with Nano-Se plus Vit E.

In conclusion, orally treatment of buck rabbits with selenium sources (Nano-Se or Org-Se) without or with vitamin E had improved semen quality and hematological and biochemical blood parameters. From the result of present experiment, it is recommended to support the commercial basal diet of 
Table 6: Effect of selenium sources and vitamin E administration and their interaction on Testosterone concentration in seminal plasma and blood serum of buck rabbits (mean \pm SE).

\begin{tabular}{|c|c|c|}
\hline \multirow{2}{*}{ Items } & \multicolumn{2}{|c|}{ Testosterone concentration } \\
\hline & Seminal plasma & Serum \\
\hline $\begin{array}{l}\text { Selenium source } \\
\text { Control } \\
\text { Org }-\mathrm{Se} \\
\mathrm{Nano}-\mathrm{Se}\end{array}$ & $\begin{array}{l}2.41 \pm 0.11^{\mathrm{b}} \\
2.73 \pm 0.17^{\mathrm{ab}} \\
3.07 \pm 0.13^{\mathrm{a}}\end{array}$ & $\begin{array}{l}0.05 \pm 0.004^{b} \\
0.13 \pm 0.02^{b} \\
1.20 \pm 0.05^{a}\end{array}$ \\
\hline Significant test & $*$ & $* *$ \\
\hline $\begin{array}{l}\text { Vit. E supplementation } \\
\text { Without Vit. E } \\
\text { With Vit. E }\end{array}$ & $\begin{array}{l}2.75 \pm 0.15 \\
2.72 \pm 0.14\end{array}$ & $\begin{array}{c}0.44 \pm 0.18 \\
0.48 \pm 0.18\end{array}$ \\
\hline Significant test & NS & NS \\
\hline $\begin{array}{l}\text { Interaction effect } \\
\text { Control without Vit. E } \\
\text { Control With vit. E } \\
\text { Org. Se without Vit. E } \\
\text { Org. S with With vit. E } \\
\text { Nano Se without Vit. E } \\
\text { Nano Se with Vit. E } \\
\end{array}$ & $\begin{array}{l}2.62 \pm 0.02^{\mathrm{ab}} \\
2.20 \pm 0.11^{\mathrm{b}} \\
2.55 \pm 0.31^{\mathrm{ab}} \\
2.91 \pm 0.13^{\mathrm{a}} \\
3.07 \pm 0.29^{\mathrm{a}} \\
3.06 \pm 0.04^{\mathrm{a}} \\
\end{array}$ & $\begin{array}{l}0.05 \pm 0.003^{b} \\
0.05 \pm 0.008^{b} \\
0.08 \pm 0.005^{b} \\
0.17 \pm 0.01^{b} \\
1.17 \pm 0.08^{a} \\
1.23 \pm 0.07^{a}\end{array}$ \\
\hline Significant test & $*$ & $* *$ \\
\hline
\end{tabular}

$\mathrm{a}, \mathrm{b}, \mathrm{c}$ Means are bearing different letters in each classification, differ significantly at $\mathrm{P}<0.05$. NS $=$ Not significant, $*=\mathrm{P}<0.05, * *=\mathrm{P}<0.01$.

Mean of three samples for each buck group.

buck NZW rabbits by orally treatment of rabbits with $0.5 \mathrm{mg}$ Organic- Se / $\mathrm{kg}$ BW to maintain their health status, protect them from heat stress and improve their semen quality in hot climate of Egypt in summer season.

\section{REFERENCES}

Abdel-Wareth, A.A., Ahmed, A.E., Hassan, H.A., Abd El-Sadek, M.S., Ghazalah, A.A. and Lohakare J. (2019). Nutritional impact of nanoselenium, garlic oil, and their combination on growth and reproductive performance of male Californian rabbits. Animal Feed Science and Technology, 249: 37-45

Ayyat M. S., Adham, A. A. and Bakry, A. K. (2018). Organic Selenium, Probiotics, and Prebiotics Effects on Growth, Blood Biochemistry, and Carcass Traits of Growing Rabbits During Summer and Winter Seasons. Biological Trace Element Research, Volume 186: 162-173. 
Dhami, A. J. and Kodagali, S. B. (1987). Correlation between biochemical and enzymatic constituents of serum of Suri buffalo bulls. Indian Journal Animal Science, 57:1283.

Duncan, D. B. (1955). Multiple Range Tests and Multiple F. Tests. Biometrics. 11:1-42.

Ebeid, T. A. (2012). Vitamin E and organic selenium enhances the antioxidative status and quality of chicken cockerel semen under high ambient temperature. Br. Poultry. Science, 53: 708-714.

El-Badry, A.S.O., H.Mahrousa, M., Mosalm, G.A.G., A.Ekram, S. and El-Aasar, T.A. (2019). Influence of ingestion of nano-selenium on growth performance, antioxidative and mutagenicity status in somatic cells of New Zealand White rabbits. Egyptian Journal, of Rabbit Science, 29 (1): 1-21.

El-Deep, M. H., Shabaan M., Assar M. H., Attia, K. h. M., and Sayed, M. A. M. (2017). Comparative effects of different dietary selenium sources on productive performance, antioxidative properties and immunity in local laying hens exposed to high ambient temperature. Journal. Animal and Poultry Production, Mansoura Univ., Vol.8 (9): 335 - 343.

EL.Gaafary, M.N. (1987). The characteristics of semen from welsh mountain and cambridge rams. Ph. D. Thesis university college of Wales, Bangor, U. K.

El-Kholy, K.H., El-Damrawy, S.Z. and Seleem, T.S.T. (2012). Improvement of rabbit's productivity and immunity by probiotic bacteria isolated from suckling mother's soft faeces. Proceedings of the 5th Science Congress of Egyptian Society for Animal Management, September 18-22, 2012, Sharm El-Sheikh, Egypt, pp: 142-157.

El-Sherbieny, M. A. S. (2004). Physiological study on farm animals. Ph.D. Thesis, Faculty of Agriculture Mansoura University, Egypt.

Fernandez, C.I., Blas, E. and Concha, C. (1994). Growth and some carcass traits of adult rabbits under high ambient temperature. Journal, World Rabbit Science, 2: 147-151.

Fortun-Lamothe, and Drouet-Viard (2002). Review : diet and immunity : current state of knowledge and research prospects for the rabbit. World Rabbit Science, 10: 25-39.

Ghodaia, A. E.B. (2016). Physiological studies on some factors affecting semen quality and preservation methods of rabbit bucks fed moringa. Ph.D. Thesis, Faculty of Agriculture, Mansora University, Egypt. 
Hashem, N.M., Abd El-Hady, A. and Hassan, O. (2013). Effect of vitamin $\mathrm{E}$ or propolis supplementation on semen quality, oxidative status and hematobiochemical changes of rabbit bucks during hot season. Livestock Science, 157: 520-526.

Hewitt, C.D.; D.J. Innes; J. Savory and M.R. Wills (1989). Normal biochemical and hematological values of blood in New Zealand White rabbits. Clinical Chem., 35 (8): 1777- 1779.

Ismail, A. M., Sedki, A. A. and Abdallah, A. G. (2003). Influence of black seed, garlic and onion supplementation on reproductive performance and immune functions in rabbits. Egyptian J. Agric. Res., 81, 11931207.

Mahima, A.K., Amit, K., Anu, R., Vinod, K. and Debashis, R. (2012). Inorganic versus organic selenium supplementation: a review. Pak. J. Biol. Sci. 15: 418-425.

Muhammad Zubair, (2017). Effects of dietary vitamin E on male reproductive system. Asian Pacific Journal of Reproduction. 145-150.

Marai, I.F.M., Abd El-Samee, A.M. and El-Gafarry, M.N. (1991). Criteria of response and adaptation to high temperature for reproductive and growth traits in rabbits. Opt. Med. A 17, 127-134.

Marai, I.F.M., Ayyat, M.S., Gabr, H.A. and Abd El-Monem, U.M. (1996). Effect of summer heat stress and its amelioration on production performance of New Zealand White adult female and male rabbits, under Egyptian conditions. On: Proceedings of 6th World Rabbits Congress, Toulouse, France, 2: 197-208.

Marai, I.F.M. and El-Kelawy, H.M. (1999). Effect of heat stress on the reproduction in females of rabbits. In: Proceedings of $1^{\text {st }}$ International Conference on Indigenous Versus Acclimatized Rabbits, El-Arish-North Sinai, Egypt.

Masukawa, T., Goto, J. and Iwata, H. (1983). Impaired metabolism of arachidonate in selenium deficient animals. Experientia, 39: 405-406.

Mohapatra, P., Swain, R.K., Mishra, S.K., Behera, T., Swain, P., Behura, N.C., Sahoo, G., Sethy, K., Bhol, B.P. and Dhama, K. (2014). Effects of dietary nano-selenium supplementation on the performance of laying grower birds. Asian J. Anim. Vet. Adv., 9: 641-652.

Nassier, F., Moundras, C., Bayle, D., Serougne, C., Gueux, E., Rock, E., Rayssiguier, Y. and Mazur, A. (1997). Effect of selenium deficiency on hepatic lipid and lipoprotein metabolism in the rat. Br. J. Nutr., 78: 493-500. 
NRC (1977). Nutrient Requirement of Domestic Animal. Nutrient Requirement of Rabbits. Second Edition National Academy of Science Washington D.C., USA.

Okachi, V. C. W and Ani, A.O. (2016). Effects of dietary inclusion of vitamin $\mathrm{C}$ and $\mathrm{E}$ on nutrient digestibility, haematological and carcass characteristics of Rabbits in a hot humid tropical environment. International Journal of Agricultural Research and Review.,4(3): 494503.

Rezvanfar, M.A., Rezvanfar, M.A., Shahverdi, A.R., Ahmadi, A., Baeeri, M., Mohammadirad, A., Abdollahi, M.( 2013). Protection of cisplatin-induced spermatotoxicity, DNA damage and chromatin abnormality by selenium nano-particles. Toxicology and Applied Pharmacology, 266 :356-365.

Saber Abd-Allah and Hashem, K. S. (2015). Selenium nanoparticles increase the testicular antioxidant activity and spermatogenesis in male rats as compared to ordinary selenium. International Journal of Advanced Research, Volume 3, Issue 1, 792-802.

Snedecor, G.W. and Cochran, W.G. (1982). Statistical Methods. 6th edition, Towa State University Press, Ames, Iowa, USA.

SPSS (2014). Statistical Package for Social Science, Version 14, Chicago, USA.

Surai, P.F. (2006). Selenium in Nutrition and Health. Nottingham University Press, Nottingham, UK.

Tietz, N. W. (1986). Fundamentals of clinical chemistry. WB Saunders Company, Philadelphia. pp. 723.

Wang, Y. (2009). Differential effects of sodium selenite and nano-Se on growth performance, tissue Se distribution, and glutathione peroxidase activity of avian broiler. Biological Trace Elements Research, 128: 184-190.

Walton, A. (1958). Improvement in the design of an artificial vagina for the rabbit. Journal of Physiology, 143:26-28.

White, I. G. (1976).Reproduction in male. Veterinary Physiology. Ed Byj. W Phillis, Phillis; Wrightscient echnica.

Yaseen, M. A., El-Azzazi, F.E., Abdel-Halim, Eman, Khalil, H.A. (2016). Effect of age, and vitamin $\mathrm{E}$ and selenium administration on semen characteristics of New Zealand White rabbit bucks. Egypt. Poultry Sci. J., 36: 501-511. 


\section{تأثير المعاملة بالنانو سيلينيوم وفيتامين هـ على جودة السائل المنوي وبعض خصائص الام فى ذكور الارانب}

نورا حمدي محمدي, حسن محمود الكيلاوي,مصطفى عبدالرحيم، محمد ناجي سبد

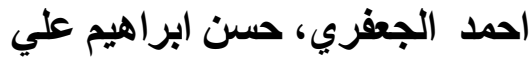

قسم الإنتاج الحيو اني و الداجني ـ كلية التكنولوجيا ولئ والتنمية ـ جامعة الزقازيق ـمصر

تهدف الدراسة إلى معرفة تأثير المعاملة بالنانو سيلينيوم (Nano-Se) ، و و السيلينيوم

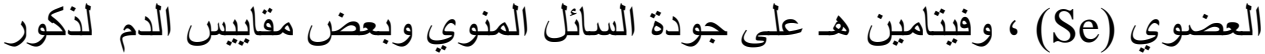

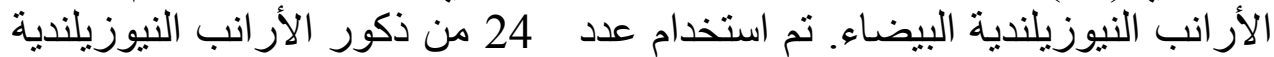



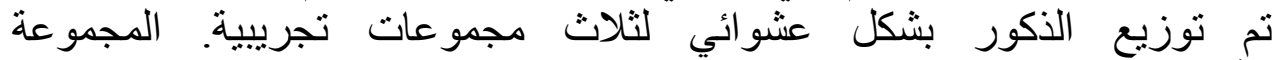
الأولى(كنترول) تم تغذيتها على على عليقه قاعدية, المجموعة الثيات الثانية غذيت على على عليقة



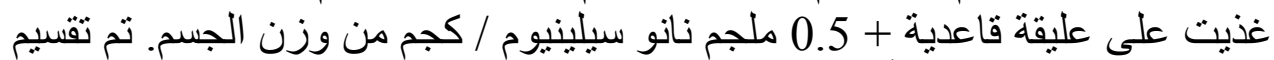

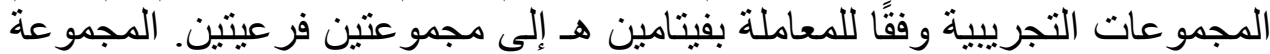

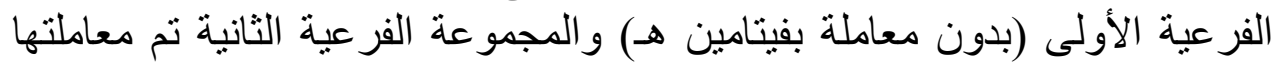

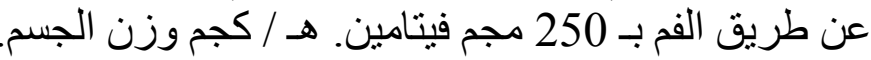

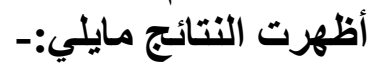

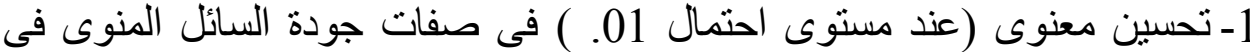
ذكور الار انب المعاملة عن طريق الفم بمصادر السلنيوم المختلفة وفيتامين هـ مقارنة فئن

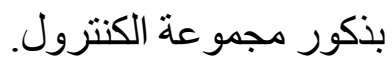
2ـ كانت تركيزات كرات الدم الحمراء ركرات الدم البيضاء, الصفائح الدموية,

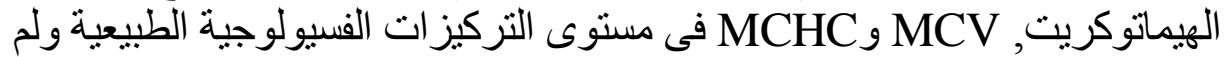

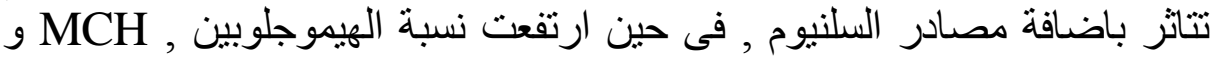

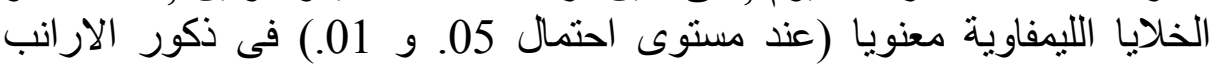

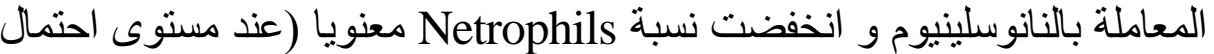
31 01. ) فى ذكور الار انب المعاملة بالنانوسلينيو مانيو.

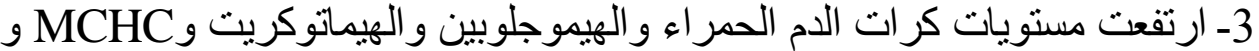

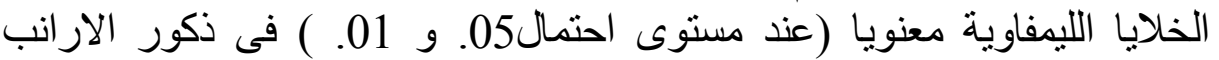

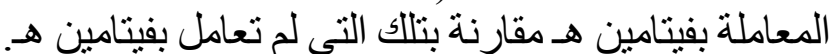

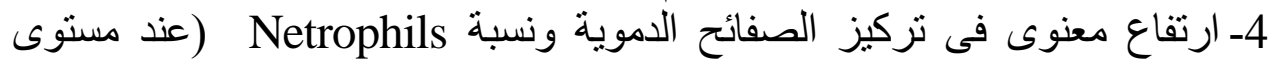
احتمال 05. و 01. ) فى ذكى ذكور الار انب التى لم تعامل بفيتامين هـ مقارنه بالمجموعة 
المعاملة بفيتامين هـ , فى حين لم تتاثر كلا من MCV, MCHبالمعاملة بقيتامين

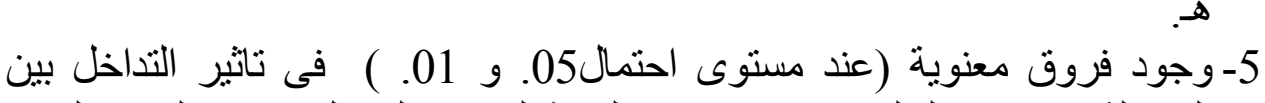

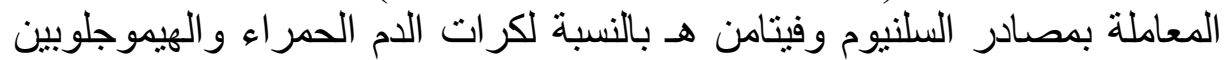

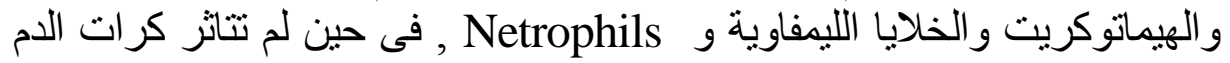

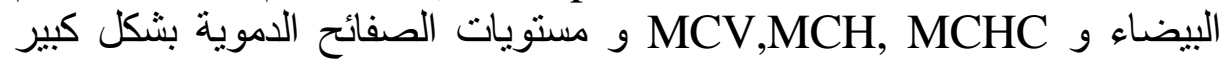
بكصادر السلنيو و وفيتامين هـ.

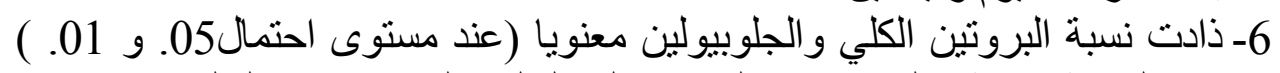

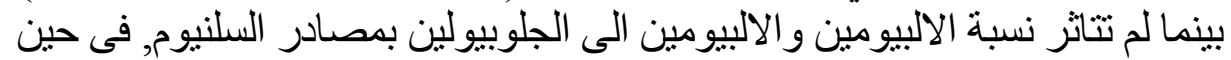

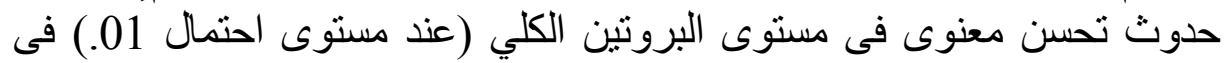



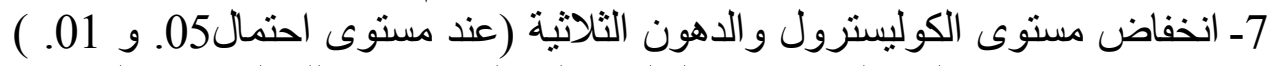

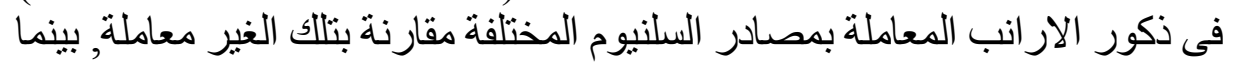

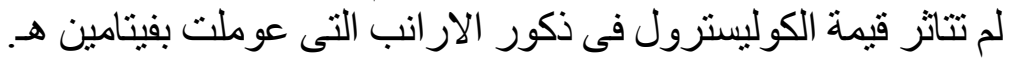

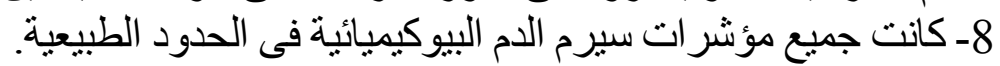

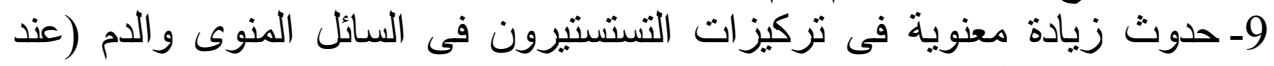

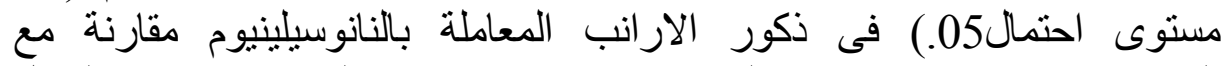

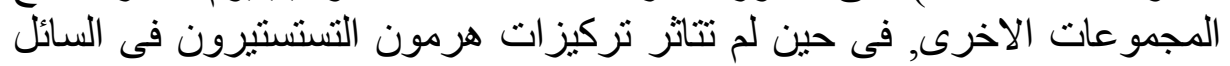

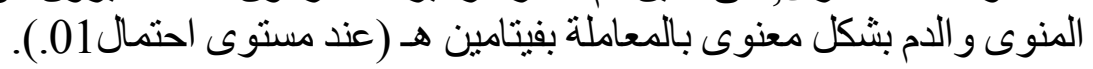

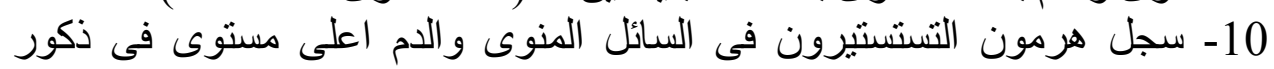

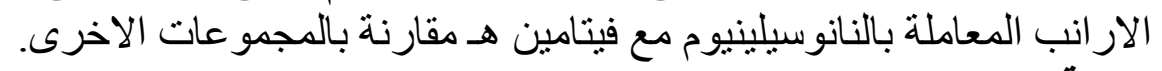

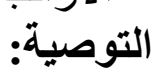
من نتائج التجربة ومن وجه النظر الاقتصادية نوصى بمعاملة ذكور الارانب النبادئ

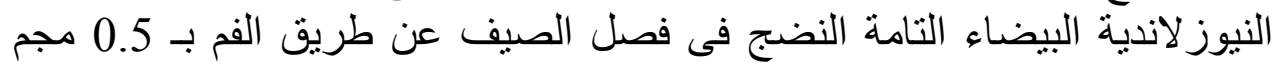

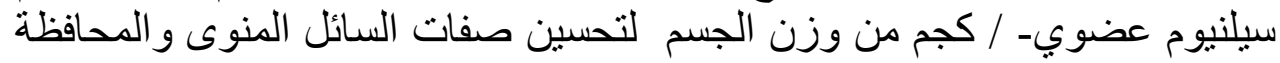

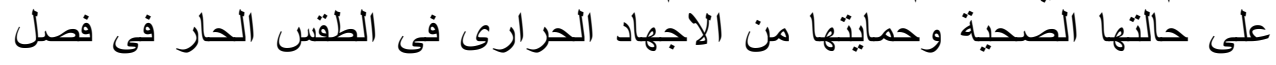

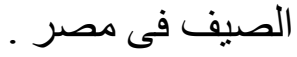


J. Product. \& Dev., 26(4): 903- 922 (2021) 